\title{
COVID-19 ve Vertikal Geçiş
}

\author{
Büşra AKGÜMÜŞ [0] ${ }^{1}$, Hüsniye DİNÇ KAYA 國
}

\begin{abstract}
ÖZ
Çin'in Hubei Eyaleti’nin Wuhan kentinde 2019 yılının Aralık ayında kaynağı bilinmeyen pnömoni vakalarının sebebi bir koronavirus olarak tanımlandı. Ardında hızla yayılan koronavirus önce Çin’de, daha sonra diğer dünya ülkelerinde vakaların görülmesine neden oldu. Şiddetli Akut Solunum Sendromu-2 (SARS-CoV-2) ve COVID-19 adı verilen virüs sebebiyle Dünya Sağlık Örgütü, Şubat 2020'de küresel salgın ilan etti. Hızlı yayılan ve ölümcül seyreden virüsün, bu süreçte enfeksiyonlara karşı daha savunmasız olan gebeler ve fetüs üzerinde oluşturacağı etki önem kazandi. COVID19 ile enfekte annelerin gebelikleri sırasında fetüse vertikal geçiş olduğu yönünde yeterli kanıt yoktur. Ancak erken doğum ve fetal distrese neden olan vakalar olduğu belirtilmektedir. Doğum anında izolasyon önlemlerinin alınması, kordonun hızlı klemplenip kesilmesi ve yenidoğanın maternal sıvılardan temizlenmesi gerekmektedir. Bu koşulların sağlandığı durumlarda anneden bebeğe vertikal geçiş olduğuna dair yeterli kanıt mevcut değildir. Doğum sonu dönemde enfeksiyonun etkin yönetiminin ve anne sütü alımının sürdürülmesinin hem maternal hem de fetal sağlığa olumlu etkileri mevcuttur. Bu derlemenin amac1, COVID-19'un gebelik, doğum, doğum sonu ve emzirme döneminde, vertikal geçiş varlığının ve geçişin olası sonuçlarının literatür doğrultusunda incelenmesidir.
\end{abstract}

Anahtar Kelimeler: COVID-19; pandemi; vertikal geçiş.

\section{COVID-19 and Vertical Transmission}

\begin{abstract}
The cause of pneumonia cases of unknown origin in Wuhan, China's Hubei Province, in December 2019 was identified as a coronavirus. Then, the rapidly spreading coronavirus led to the emergence of cases first in China and then in other countries of the world. The World Health Organization declared a global pandemic in February 2020 due to the virus called Severe Acute Respiratory Syndrome-2 (SARS-CoV-2) and COVID-19. The effect of the virus, which has spread rapidly and is fatal, on pregnant women and fetuses, who are more vulnerable to infections in this process, has gained importance. There is no enough evidence indicating vertical transmission to the fetus during pregnancy of mothers infected with COVID-19. However, there have been cases causing preterm labor and fetal distress. It is necessary to take isolation measures, to clamp and cut the cord quickly, and to clean the newborn from maternal fluids during childbirth. There is no enough evidence of vertical transmission from the mother to the infant in cases when these conditions are met. The effective management of infection and maintaining breast milk intake in the postpartum period have positive effects on both maternal and fetal health. This review aimed to examine the presence of vertical transmission of COVID19 during pregnancy, birth, postpartum and breastfeeding and the possible consequences of transmission based on scientific data.
\end{abstract}

Keywords: COVID-19; pandemic; vertical transmission.

\section{GİRŞ̧}

Koronavirus; Çin'in Hubei Eyaleti'nin başkenti Wuhan'da 2019 yılının Aralık ayında kaynağı bilinmeyen pnömoni vakaları olarak ortaya çıktı. DSÖ tarafından 11 Mart 2019 tarihinde küresel salgın ilan edildi $(1,2)$.

\footnotetext{
1 SBÜ Ankara Dr. Sami Ulus Kadın Doğum Çocuk Sağlığı ve Hastalıkları Eğitim Araştırma Hastanesi, İstanbul Üniversitesi-Cerrahpaşa Lisansüstü Eğitim Enstitüsü Ebelik Anabilim Dalı, İstanbul, TÜRKIYY

2 İstanbul Üniversitesi-Cerrahpaşa Sağlık Bilimleri Fakültesi Ebelik Bölümü, İstanbul, TÜRKIYE
} 
Koronavirus-19 hastalığının insandan insana geçişi damlacık ve doğrudan temas yoluyla gerçekleşmektedir. Ayrıca kişi enfekte bir yüzeye temas ettikten sonra ellerini göz, burun ya da ağzına temas ettirmesiyle enfekte olabilir. İnkübasyon süresi ortalama dört gün (2 ile 7 gün arasında) sürmekte ve semptomatik hastaların çoğu ateş, öksürük, tat ya da koku kaybı yaşarken, bazı vakalar pnömoni ve akut solunum sıkıntısı sendromuna dönüşmektedir. COVID-19 kaynaklı ölüm oranları \%1-2 arasında değişmekle birlikte, Şiddetli Akut Solunum Sendromu (SARS-CoV) veya Orta Doğu Solunum Sendromu (MERS-CoV) kaynaklı ölümlerden daha düşük bir vaka ölüm oranına sahiptir (2). Gebelik, kadınları viral enfeksiyonlara karşı savunmasız hale getiren, bağışıklık sisteminde kısmi baskılanmaya sebep olan bir süreçtir (5). Bu süreçte toraksın transver çapındaki artış ve diyafram seviyesinin yükselmesiyle hipoksiye karşı tolerans azalmaktadır. Akciğer hacmindeki değişiklikler ve vazodilatasyon üst solunum yolunda mukozal ödeme ve sekresyonların artmasına neden olabilmektedir. Ayrıca hücresel bağışıklıktaki değişiklikler, gebe kadının virüsler gibi hücre içi organizmaların neden olabileceği enfeksiyonlara karşı toleransını azaltmaktadır (6). $\mathrm{Bu}$ sebeplerle gebeler COVID-19'un gebelik sirasinda ve sonrasinda hem kendileri hem de bebekleri üzerinde oluşabilecek etkileri nedeniyle yüksek riskli grup olarak kabul edilmektedir (7). Vertikal geçiş, enfeksiyon patojeninin gebelik döneminde anneden fetüse uteroplasental yol ile; doğumda vücut sıvıs1 teması veya doğrudan temas ile; doğum sonu dönemde anneden yenidoğana temas veya emzirme yolu ile bulaşması olarak tanımlanmaktadır (8). COVID-19'un gebe ve fetüs üzerindeki olası etkileri, anne ve yenidoğanın uygun yönetimi ve emzirmenin sürdürülebilmesi büyük bir endişe yaratmaktadır (9). Vertikal bulaşın birçok virüs için doğrulanmış olması, abortus, intrauterin gelişme geriliği, preterm doğum vb. olumsuz perinatal sonuçlara yol açması endişeyi artırmaktadır. Artan bu endişe 'CCOVID-19'un vertikal geçişi mümkün mü?’' sorusunu bir tartışma konusu haline getirmektedir.

$\mathrm{Bu}$ derlemenin amac1, COVID-19'un gebelik, doğum, doğum sonu ve emzirme döneminde, vertikal geçiş varlığının ve geçişin olası sonuçlarının literatür doğrultusunda incelenmesidir.

\section{Gebelik Döneminde COVID-19 ve Vertikal Geçiş}

Vakalar ilk kez ortaya çıktığından bu yana gebelikte COVID-19 seyri ve vertikal geçiş üzerine araştırmalar yayınlanmıştır. $\mathrm{Bu}$ araştırmaların çoğu vertikal geçiş ihtimalinin düşük olduğunu desteklese de gebelik sırasında COVID-19'un şiddetli maternal morbidite ile ilişkili olabileceğini ve maternal-fetal geçiş olasılığının tamamen göz ardı edilemeyeceğini destekleyen çalışmalarda mevcuttur $(3,6)$.

Retrospektif olarak incelenen COVID-19 tanısı almış dokuz gebenin ( $\geq 36$ hafta) dahil edildiği çalışmada (10), gebelerin tümünün sezaryen ile doğumu gerçekleşmiştir. Amniyotik sıvı, kordon kanı ve yenidoğanlardan alınan boğaz sürüntülerinde test sonuçlarının negatif olduğu bildirilmiştir. Araştırmacılar gebeliğin son döneminde COVID-19 tanısı alan kadınlarda intrauterin vertikal geçişe dair kanıt olmadığını ifade etmişlerdir (10). Ashraf ve arkadaşlarının (11) yaptığı 21 araştırmayı kapsayan sistematik derlemede enfekte olan 90 gebe (28-40 hafta) ve 92 yenidoğan ( 2 adet ikiz doğum) klinik olarak değerlendirilmiştir. Gebelerdeki en yaygın semptomların ateş, öksürük ve nefes darlığ1 olduğu görülmüştür. Yenidoğanlar vertikal bulaş olasılı̆̆ açısından test edilmiştir. Seksen iki yenidoğanın test sonuçları negatif, dört yenidoğanın test sonuçları pozitif, bir ölüm doğum ve bir neonatal ölüm olarak rapor edilmiştir. Ayrıca COVID19 'un en sik fetal distrese ve erken doğuma neden olduğu bununla birlikte vertikal bulaş olasılığının düşük olduğu ifade edilmiştir (11).

Gebeliklerinin üçüncü trimesterinde olan 64 gebenin değerlendirildiği bir başka çalışmada (12); ölü doğum, neonatal ölüm ve vertikal bulaş vakasının olmadığı bildirilmiştir. Liu ve arkadaşlarının (13) COVID-19 tanısı almış 19 gebeden doğan yenidoğanları incelendiği çalışmada; tüm yenidoğanların boğaz sürüntü, idrar ve dışkısında SARS-CoV-2 testi negatif olarak izlenmiştir. Amniyotik sıvı ve kord kanı analizleri de negatif olarak rapor edilmiştir (13).

Nie ve arkadaşlarının (14) yaptığı çalışmada; ikinci trimester ve üçüncü trimester da COVID-19 tanısı almış gebelerden doğan 26 yenidoğan vertikal bulaş yönünden incelenmiştir. Yalnızca bir yenidoğanda boğaz sürüntüsü ve gögüs röntgeninde COVID-19 tanısı doğrulanmıştır. Ancak kordon kanı ve plasenta örneklerinde SARS-CoV2 negatif olarak bulunmuştur (14). 18'i vajinal doğum ile sonlandırılan 23 gebeliğin incelendiği çalışmada (15) ise yenidoğanların tümünün plasenta ve kordon kanı numunelerinin SARS-CoV-2 yönünden negatif olduğu rapor edilmiştir (15).

Bir başka olgu sunumunda (16); gebeliğin 2. trimesterinde (19. hafta) miyalji, yüksek ateş $\left(39.2^{\circ} \mathrm{C}\right)$, yorgunluk, ishal ve iki günlük kuru öksürük ile kliniğe başvuran bir gebenin nazofaringeal sürüntüsünde SARS-CoV-2 pozitif olarak test edilmiştir. Oral asetaminofen verilerek evde istirahat önerilen gebe iki gün sonra şiddetli uterus kanaması ve ateş ile tekrar kliniğe başvurmuştur. On saatlik bir doğum eylemi sonucu vajinal yolla ölü doğum gerçekleşmiştir. Doğumdan birkaç dakika sonra test edilen ağı, mekonyum ve kan örnekleri negatif olarak bildirilmiştir. Ancak plasentanın fetal yüzünden alının iki swab ve biyopsi örneğinin analizinde SARS-CoV-2 pozitif olarak bildirilmiştir. Maternal enfeksiyonun kısa süre önce tespit edilmesi göz önüne alındığında enfeksiyonun plasental bariyeri geçip geçemeyeceği daha fazla çalışma ile desteklenmesi gerektiği ifade edilmiştir (16).

Bir meta-analizde (3); 936 yenidoğan SARS-CoV-2 varlığ1 yönünden incelenmiştir. Kord kanında \%2,9, plasenta örneklerinde $\% 7,7$, dışk1 ve rektal sürüntülerde $\% 9,7$ oranında rastlandığı, amniyotik sıvı ve idrar örneklerinde ise rastlanmadığ sira COVID-19 ile enfekte annelerden alınan plasental histolojik değerlendirmede vasküler malperfüzyon, fibrin birikimi ve kronik villitis veya intervillositis gibi patolojik parametrelerin analiz edildiği seride 15 plasentadan 12'si maternal vasküler malperfüzyon kanıtı gösterirken; dört plasentada merkezi ve periferik villöz enfarktüsler gözlenmiştir. SARS-CoV-2 pozitif 20 kadının plasentasının analiz edildiği seride ise 10 plasentada vasküler malperfüzyon gözlenmiştir. Ancak bu sonuçlar uteroplasental iletimin ve plasental doku üzerindeki viral etkilerin ortaya koyacağı sonuçlar için yeterli değildir (3). Çalışmalar 3. trimesterde enfekte olan anneden fetüse plasental yolla vertikal geçiş olasılığının düşük olduğunu 
göstermektedir. Erken gebelik haftalarında enfekte olan anneden fetüse vertikal geçiş ile ilgili olarak sınırlı veri olmasının yanı sıra preterm eylem, fetal distres ve abortus olasılığını artırdığını destekleyen çalışmalar mevcuttur. Ancak COVID-19'un gebelik döneminde anneden fetüse plasental yolla vertikal geçişini ve olası bir geçişin fetüs üzerindeki etkilerini inceleyen daha çok çalışmaya ihtiyaç vardir $(3,6,11)$.

\section{Doğum Eyleminde COVID-19 ve Vertikal Geçiş}

COVID-19 ile enfekte olmuş gebelerde, enfeksiyon varlığ tek başına doğum için bir endikasyon değildir. Doğumun zamanlaması ve şekli, gebenin ve fetüsün klinik durumu, gebelik haftası gibi faktörler değerlendirilerek şekillenmelidir. Çünkü doğum şekli ve zamanının vertikal geçiş üzerine etkisi hakkında fikir birliği bulunmamaktadır.

Zaigham ve arkadaşlarının (6) 108 gebeyi dahil ettikleri sistematik derlemede; doğumların \%92'si sezaryen ile gerçekleşmiştir ve sezaryen endikasyonu olarak en sık fetal distres gösterilmiştir. Sezaryen ile doğumu gerçekleşen ve anneden izole edilen bir yenidoğanda doğumdan 36 saat sonra alınan nazofaringeal sürüntüde SARS-CoV-2 pozitif olarak test edilmiştir. Kordon kanı ve plasenta örneklerinin negatif olması doğum anında bulaşın gerçekleşmiş olabileceği ihtimalini desteklemektedir. Bu sebeple doğum anında ki vertikal bulaşın göz ard1 edilmemesi gerekmektedir. Literatürde bulunan retrospektif yapılan bir diğer çalışmada ise (17); 24 gebe vajinal doğum, 18 gebe ise sezaryen doğum gerçekleştirmiştir. Bu gebelerden 31'i miadında doğum yaparken, beş gebe spontan preterm eylem, altı gebe ise elektif sezaryen gerçekleştirilmiştir. Vajinal yolla gerçekleşen bir doğumda, COVID-19 pozitif annede şiddetli kanama olması sebebiyle yenidoğan anneden ayrılmıştır. Anne ile yenidoğanın teması gerçekleşmemiş ve yenidoğan anne tarafindan emzirilmemiştir. İzole edilen yenidoğanın 3 gün sonraki testi SARS-CoV-2 pozitif olarak rapor edilmiştir. İntrapartum dönemde SARS-CoV-2 vertikal bulaş riski düşük olarak rapor edilse de riskin göz ardı edilemeyeceği bildirilmiştir. COVID-19 semptomları hafif seyreden gebelerde vajinal doğumun güvenli ve vertikal bulaş riskinin düşük olduğu ifade edilirken, sezaryenin ciddi solunum problemi olan vakalarda uygulanması önerilmektedir (17).

Bir başka çalışmada (18) ise; vajinal yolla doğum yapan COVID-19 ile enfekte olan 10 gebe rapor edilmiştir. Gebelere negatif basınçlı izole bir doğum odasında nazal katater ile oksijen inhalasyonu uygulanırken, cerrahi maske kullanılmış ve gebelerin hareketine izin verilmiştir. Doğumdan sonra kord klempleme işlemi hızlı bir şekilde yapılmış ve kord erken kesilip temizlenmiştir. Yenidoğan anneden ayrılmış, yapay beslenme gerçekleştirilmiştir. Yenidoğanların hiçbirinde SARS-CoV-2 pozitif test edilmemiştir. $\mathrm{Bu}$ durumda uygun doğum ortamının hazırlanması ve koruyucu önlemlerin iyi alınması ile vajinal doğumun enfekte annelerde güvenli olduğu ifade edilebilir.

Gebelik haftası $36+6$ ile $38+2$ hafta arasında değişen beş gebenin vajinal yol ile doğumunun gerçekleştiği çalışmada doğumların hepsi canlı doğum ile sonuçlanmıştır. Vajinal sekresyonları test edilen gebelerde SAR-CoV-2 pozitifliğine rastlanmamıştır. Yenidoğanların hiçbirinde
SARS-CoV-2 pozitif rapor edilmemiştir. Vajinal doğumun enfekte gebeler için güvenli olduğu rapor edilmiştir (19). COVID-19 ile enfekte olmuş gebelerin doğum şeklinde fikir birliği bulunmasa da doğum yönetimi hakkında fikir birliğinin oluştuğu noktalar mevcuttur. Gebenin klinik durumunun kötüleşmesi, ventilasyon zorluğu, fetal distres gibi durumlarda sezaryen doğum önerilmektedir. Vajinal doğumda ise doğum esnasında enfekte gebelerden yayılacak damlacık veya vajinal sekresyonlarla gerçekleşecek vertikal geçiş ihtimali tam anlamıyla dışlanamamaktadır. Vajinal doğum gerçekleştirilecek ortamın negatif basıç̧lı ve izole olması, gebenin maskesinin takılı olması, gögüs hizasından üst kısmında şeffaf bir örtüyle örtülü olması, doğum sonu kordun hızlı klemplenmesi ve kesilmesi, bebeğin anneden izole ortamda bulundurulması doğum anında gerçekleşecek vertikal bulaş riskini azaltmaya yardımcı olacaktır.

\section{Doğum Sonu Dönem ve Emzirmede COVID-19 Vertikal Geçiş}

DSÖ, anne sütünü, bebekler için en uygun besin olarak görmektedir. Doğumdan sonra ilk 6 ay yalnızca anne sütü ile beslenmeleri ve 6 . aydan sonra tamamlayıc1 ek besinlerle birlikte emzirmenin sürülmesi gerektiğini bildirmektedir (20). Bir diğer önemli nokta anne-bebek bağlanmasıdır. Bağlanma, anne ile bebek arasında gebelik döneminde başlayan, doğum ve doğum sonu dönemde anne ile bebek arasında eşzamanlı ortaya çıkan ve devamlılık gösteren bir süreçtir. $\mathrm{Bu}$ sürecin sekteye uğraması yaşamın ileri evrelerinde bebekte fizyolojik ve psikolojik eksikliklere neden olabilmektedir (21). Doğum sonu dönemde COVID-19 ile enfekte anneden yenidoğana hem emzirme ile vertikal geçiş hem de temas ya da solunum damlacıkları ile bulaş endişe yaratan bir durumdur. COVID-19'un anne sütü ile beslenmeyle bulaştı̆̆ı konusunda mevcut güçlü kanıt bulunmamaktadır (22).

Chen ve arkadaşlarının (10) yaptığı bir çalışmada COVID19 ile enfekte olan dokuz kadının anne sütünde SARSCoV-2 tespit edilmezken; Wu ve arkadaşlarının (19); 13 kadın ile yaptığı çalışmada bir anne sütü örneğinde pozitif nükleik asit sonucu rapor edilmiştir. Bu enfekte kadından iki gün sonra tekrar alınan test negatif olarak rapor edilmiştir. Ancak bu anne sütü yoluyla viral bulaşma olasılığının göz ardı edilemeyeceğini destekleyen bir sonuçtur.

Emzirmenin hem anne hem de yenidoğan açısından yararlarının yanı sıra, yenidoğanı bakteriyel ve viral enfeksiyonların getireceği morbite ve mortaliteden korumaktadır. COVID-19 ile enfekte anne ve yenidoğanın birbirinden izole edilmesi ve bu süreçte emzirmenin sürdürülmemesi kararı, anne veya bebeğin klinik durumundaki kötüleşme, emzirme isteği, izolasyon koşulları, riskler ve yararlar değerlendirilerek, ebeveynlerin tercihleri göz önüne alınarak verilmelidir $(23,24)$.

Ten tene temas ve emzirmenin bebeğe olan faydaları göz önüne alındığında DSÖ anne ve bebeğin aynı ortamda kalmasını, tentene temasın sağlanmasını, emzirme ve temas durumunda annenin maske ve eldiven kullanmasinı desteklemektedir. Bebeğe dokunmadan önce el hijyeninin sağlaması ve dokunulan tüm yüzeylerin dezenfekte edilmesini önermektedir. Annenin klinik durumunun kötü olduğu ya da bebeğine bakım vermeye devam edemediği 
durumlarda sütün sağılarak COVID-19 açısından risk altında olmayan sağlıklı biri tarafinda yenidoğanın beslenmesi önerilmektedir $(25,26)$.

\section{SONUÇ}

COVID-19'un tüm dünyayı etkisi altına almış olması, enfeksiyonlara karşı toleransı azalan gebeler için endişe yaratan bir durum haline gelmiştir. Gebelikte olası bir COVID-19 ile enfekte olma durumunun hem anne hem de fetüs üzerindeki etkileri tam anlamıyla bilinmemektedir. Yapılan çalışmalar gebelik sırasında enfekte olan annelerin bebeklerine vertikal bulaş olasılığının düşük olduğunu göstermektedir. Doğum sirasında enfekte olan annenin vajinal sekresyonları ve solunum damlacıklarıyla temasın önlenmesi, kordonun hızlı kesilip, yenidoğanın maternal sıvılardan temizlenmesi enfeksiyonun vertikal bulaş olasılığını düşürmek için desteklenen uygulamalardır. Doğum sonu dönemde enfekte olan anneden bulaşabilecek enfeksiyon ile emzirme ve ten tene temasın fayda zarar değerlendirmesi yapıldığında; enfeksiyon hafif seyreden annelerde ve bebeğiyle birlikte bulunmayı tercih eden annelerde gerekli temas önlemleri alındığında anne ve yenidoğanın bir arada bulunması önerilmektedir. $\mathrm{Bu}$ derlemede incelediğimiz veriler 1şığında "COVID-19'un vertikal geçişi mümkün mü?', sorusuna kesin kanıtlar sunabilecek daha çok çalışmaya ihtiyaç vardır.

Yazarların Katkıları: Fikir/Kavram: B.A., H.D.K.; Tasarım: B.A., H.D.K.; Literatür Taraması: B.A.; Makale Yazımı: B.A., H.D.K.; Eleştirel İnceleme: H.D.K.

\section{KAYNAKLAR}

1. World Health Organization [Internet]. WHO Coronavirus Disease (COVID-19) Dash-board. 2020 [Updated: 2020 November 28; Cited: 2020 November 28]. Available from: https://covid19.who.int/

2. Guan WJ, Ni ZY, Hu Y, Liang WH, Ou CQ, He JX, et al. Clinical characteristics of coronavirus disease 2019 in China. N Engl J Med. 2020; 382(18): 1708-20.

3. Yang Z, Liu Y. Vertical Transmission of severe acute respiratory syndrome coronavirus 2: a systematic review. Am J Perinatol. 2020; 37(10): 1055.

4. Ünal N. Yeni koranavirüs hastalığının etiyolojisi. Avrasya SBD. 2020; 3: 95-101.

5. Özcan H, Elkoca A, Yalçın Ö. COVID-19 Enfeksiyonu ve gebelik üzerindeki etkile-ri. Anadolu Klin. 2020; 25(1): 43-50.

6. Zaigham M, Andersson O. Maternal and perinatal outcomes with COVID-19: A sys-tematic review of 108 pregnancies. Acta Obstet Gynecol Scand. 2020; 99(7): 823-29.

7. Allotey J, Stallings E, Bonet M, Yap M, Chatterjee S, Kew T, et al. Clinical manifesta-tions, risk factors, and maternal and perinatal outcomes of coronavirus disease 2019 in pregnancy: living systematic review and meta-analysis. BMJ. 2020; 370.

8. Kotlyar A, Grechukhina O, Chen A, Popkhadze S, Grimshaw A, Tal O, et al. Vertical transmission of COVID-19: a systematic review and meta-analysis. Am Journal Obstet Gynecol. 2020; 224(1): 35-53.

9. Asadi L, Tabatabaei RS, Safinejad H, Mohammadi M. New corona virus (COVID-19) management in pregnancy and childbirth. Arch Clin Infect Dis. 2020; 15(COVID-19): e102938.

10. Chen H, Guo J, Wang C, Luo F, Yu X, Zhang W, et al. Clinical characteristics and int-rauterine vertical transmission potential of COVID-19 infection in nine pregnant wo-men: a retrospective review of medical records. The Lancet. 2020; 395(10226): 809-15.

11. Ashraf MA, Keshavarz P, Hosseinpour P, Erfani A, Roshanshad A, Pourdast, et al. Co-ronavirus disease 2019 (COVID-19): A systematic review of pregnancy and the possi-bility of vertical transmission. J Reprod Infertil. 2020; 21(3): 157.

12. Pierce Williams RA, Burd J, Felder L, Khoury R, Bernstein PS, Avila K, et al. Clinical course of severe and critical COVID-19 in hospitalized pregnancies: A US cohort study. Am J Obstet Gynecol MFM. 2020; 2(3): 100134.

13. Liu W, Wang J, Li W, Zhou Z, LiuS, Rong Z. Clinical characteristics of 19 neonates born to mothers with COVID-19. Front Med. 2020; 14(2): 1-6.

14. Nie R, Wang S, Yang Q, Fan CF, Liu YL, He WC, et al. Clinical features and the ma-ternal and neonatal outcomes of pregnant women with coronavirus disease 2019. MedRxiv. 2020; 27: 1-24.

15. Pereira A, Cruz-Melguizo S, Adrien M, Fuentes L, Marin E, Perez-Medina T. Clinical course of coronavirus disease-2019 (COVID-19) in pregnancy. Acta Obstet Gynecol Scand. 2020; 99(7): 839-47

16. Baud D, Greub G, Favre G, Gengler C, Jaton K, Dubruc E, et al. Second-trimester mis-carriage in a pregnant woman with SARS-CoV-2 infection. JAMA. 2020; 323(21): 2198-200.

17. Ferrazzi E, Frigerio L, Savasi V, Vergani P, Prefumo F, Barresi S, et al. Vaginal deli-very in SARS-CoV-2infected pregnant women in Northern Italy: A retrospective analysis. BJOG. 2020; 127(9): 1116-21.

18. Liao J, He X, Gong Q, Yang L, Zhou, Li J. Analysis of vaginal delivery outcomes among pregnant women in Wuhan, China during the COVID-19 pandemic. Int J Gyne-col Obstet. 2020; 150(1): 53-7.

19. Wu Y, Liu C, Dong L, Zhang C, Chen Y, Liu J, et al. Coronavirus disease 2019 among pregnant Chinese women: case series data on the safety of vaginal birth and breastfee-ding. BJOG. 2020; 127(9): 1109-15.

20. World Health Organization. Guiding principles for feeding infants and young children during emergencies. Geneva: WHO Library Cataloguing-inPublication Data; 2004.

21. Çaltekin İ, Çaltekin M. Sağlık Bilimleri Alanında Araştırma Makaleleri - 2. Maternal Bağlanma Kuramı. Ankara: Gece Akademi: 2019; 11-27.

22. El-Gilany AH. Covid-19 and breastfeeding. Asploro J Biomed Clin Case Rep. 2020; 3(2): 102-5.

23. Davanzo R, Moro G, Sandri F, Agosti M, Moretti C, Mosca, F. Breastfeeding and co-ronavirus disease2019: Ad interim indications of the Italian Society of Neonatology endorsed by the Union of European Neonatal and Perinatal Societies. Matern Child Nutr. 2020; 16(3): e13010.

24. Yang N, Che S, Zhang J, Wang X, Tang Y, Wang J, et al. Breastfeeding of infants born to mothers with COVID-19: A rapid review. MedRxiv. 2020; 8(10): 618- 28. 
25. World Health Organization [Internet]. Coronavirus disease (COVID-19): Breastfee-ding. 2020. [Updated: 2020 December 23; Cited: 2020 December 28]. Available from: https://www.who.int/news-room/q-adetail/coronavirus-disease-covid-19-breastfeeding.

26. Bfmed.org [Internet]. Chicago: Academy of Breastfeeding Medicine on Coronavirus 2019 (Covid19). 2020. [Updated: 2020 March 10; Cited: 2020 December 28]. Avai-lable from: https://www.bfmed.org/abm-statement-coronavirus 